\title{
MOBILIDADE URBANA: Uma análise a partir do Transporte Coletivo Urbano na cidade de São Miguel do Oeste - SC
}

\author{
Leandra Daiprai \\ UTFPR (Universidade Tecnológica Federal do Paraná) \\ E-mail: leandradaiprai@hotmail.com
}

\section{RESUMO}

A mobilidade urbana diz respeito à forma como os deslocamentos de pessoas e cargas acontecem na malha urbana. O objetivo do trabalho é analisa-la através do transporte coletivo urbano na cidade de São Miguel do Oeste - SC. Este transporte tem como função permitir o deslocamento de um número maior de usuários em um único veículo, otimizando o deslocamento e reduzindo o grande número de automóveis que circulam na cidade. Para tal, elaborou-se um questionário do tipo survey, aplicado em uma amostra de 100 pessoas, usuárias do transporte coletivo. Conclui-se que o este tipo de transporte é utilizado principalmente por jovens mulheres e o principal motivo do deslocamento acontece para fins de estudo. Ele não atende a malha urbana em sua totalidade, sendo necessário repensar na infraestrutura do sistema e em políticas públicas que incentivem o uso, como uma alternativa positiva à mobilidade urbana do município.

Palavras-chave: Mobilidade urbana. Transporte coletivo. São Miguel do Oeste.

\begin{abstract}
Urban mobility concerns about how the displacements of people and cargo take place in the urban mesh. The intention of the study is to analyze urban mobility through collective transportation, in the city of São Miguel do Oeste - SC. This type of transportation has the purpose to allow a great number of users in a single vehicle, optimizing displacement and reducing a large number of automobiles that circulate through the city. For this understanding, a questionnaire of the type survey was elaborated and applied in a sample of a hundred people, all users of the collective transportation of the city. It is concluded that transportation is mainly used by young women, and for studying purposes. It does not serve the urban mesh in its entirety, and it is necessary to rethink the system's infrastructure and public policies that encourage its use as a positive alternative to the urban mobility of the municipality.
\end{abstract}

Keywords: Urban mobility. Collective transportation.São Miguel do Oeste. 


\section{INTRODUÇÃO}

As ações do homem sempre afetaram de forma direta ou indireta o meio ambiente. Cada solução adotada, cada intervenção, sempre causou e em algumas situações ainda vem causando algum tipo de impacto, tanto positivo quanto negativo no planeta. A crise ambiental atual tem influência direta na forma com a qual o ser humano se apropria do meio, causando desmatamentos, degradação do solo, queimadas, etc., sempre pensando em seu bem-estar e em alguma forma de tornar a vida mais fácil, ou simplesmente em algumas intervenções realizadas para garantir sua subsistência, sem pensar nas consequências das suas atitudes em longo prazo ou imaginando os problemas que seriam causados por meio delas.

A população humana passou de 1 bilhão, em 1800, para 7 bilhões, duzentos anos mais tarde. As pressões que esses seres têm feito sobre os recursos do planeta cresceram de forma mais do que proporcional e são visíveis no ambiente construído, como as cidades, hoje o lar da maior parte da espécie humana (Silva, 2014).

O processo de urbanização sempre causa impacto ambiental. A poluição dos rios gerada pela localização estratégica das cidades próximas a eles ou a superpopulação do planeta, que continua em constante crescimento, são processos que vem agravando os problemas ambientais.

Há a necessidade de que as pessoas se desloquem dentro da malha urbana, seja para morar, trabalhar, estudar, etc. e consequentemente, esse deslocamento também impacta no cotidiano, no meio ambiente, no trabalho e na qualidade de vida destas pessoas.

Estudar a mobilidade urbana em uma cidade de menor porte não é algo comum, já que, na maioria das vezes, é necessário que existam problemas de grandes proporções para que o tema seja abordado no contexto científico. Entretanto, os problemas relacionados a esse fim interferem diretamente na vida da população das cidades de menor porte.

Quando os deslocamentos começam a precisar do dobro do tempo para acontecer, quando o planejamento urbano tem como foco apenas os veículos particulares ou quando não há planejamento voltado para a circulação de pedestres, é necessário repensar a forma de fazer planejamento urbano. As cidades brasileiras vêm sendo pensadas a partir de carros e motos, de forma a não priorizar e promover o incentivo ao uso de transportes menos poluentes e que possam permitir melhor qualidade de vida.

Pensar em melhoria na mobilidade urbana das cidades é pensar diretamente em melhorias em aspectos econômicos, ambientais e sociais e, consequentemente, estas melhorias viabilizam ou refletem em melhorias na qualidade de vida da população. Nesse aspecto, o desenvolvimento regional está atrelado a essas melhorias.

A condução de um estudo numa cidade de menor porte faz perceber que esse problema não se dá apenas nas metrópoles ou grandes cidades. Por menor que uma cidade seja, ela já enfrenta algum tipo de problema relacionado a esse tema, por isso é necessário repensar em como a mobilidade veio sendo encarada e priorizar a qualidade de vida da população, já que de nada adianta pensarmos na cidade esquecendo-se de quem a utiliza.

O município de São Miguel do Oeste, que possui aproximadamente 40 mil habitantes, em seu Plano Diretor Municipal, no seu Art. 23 traz que: "O Programa de Mobilidade buscará desenvolver um conjunto de políticas de transporte e circulação para proporcionar o acesso amplo e democrático ao espaço urbano, através da priorização das pessoas com a implantação e melhoramento dos equipamentos de circulação inclusivas e ambientalmente sustentáveis".

Esse programa deveria ter sido implantado no ano de 2013, porém, nada foi feito até então, evidenciando a necessidade de uma pesquisa que realize uma avaliação acerca da mobilidade urbana no município.

É necessário entender como a mobilidade urbana acontece hoje em cada cidade para que então, se tenham condições de realizar intervenções com soluções não apenas pontuais ou de caráter imediatista, mas que possam ser justificadas em longo prazo e que promovam melhorias em todo o sistema que a mobilidade urbana engloba. Então, como analisar a mobilidade urbana na cidade de São Miguel do Oeste - SC? 
No presente estudo, o transporte urbano foi definido como objeto de análise, pois ele contempla um público duplo: pedestres e passageiros. Todo passageiro é pedestre antes de adentrar em um ônibus, o que permite também, analisar não apenas a satisfação quanto ao transporte, mas também quanto à qualidade da infraestrutura viária do caminhamento enquanto pedestre até o ponto de ônibus.

A escolha do município de São Miguel do Oeste se deu pelo fato de que a grande maioria dos estudos sobre mobilidade urbana se dá em cidades de maior porte, como se as cidades com porte menor não tivessem problemas relacionados a este fim, e que afetam diariamente e diretamente a qualidade de vida da população, mesmo não apresentando quilômetros de congestionamento diários. $E$ mais, por que esperar que a mobilidade urbana de uma cidade se transforme em um verdadeiro caos para que se pense em soluções?

\subsection{Metodologia}

A pesquisa se caracteriza por ser qualitativa e quantitativa. A pesquisa qualitativa foi realizada através da pesquisa bibliográfica e documental. A pesquisa quantitativa foi realizada através da entrevista para verificar qual o perfil do usuário do transporte coletivo bem como, o grau de satisfação do mesmo com relação a esse tipo de transporte. A entrevista fez parte da coleta de dados e teve um roteiro, com questões elaboradas a partir do referencial teórico que levantou os pontos para serem discutidos e/ou respondidos e foi do tipo survey.

Para analisar o grau de satisfação, foram realizados estudos e levantamento acerca de trabalhos que procuraram analisar a mobilidade urbana. Optou-se por trabalhar com base em teses, dissertações e/ou artigos publicados recentemente. Analisou-se o questionário aplicado em dois trabalhos selecionados, de Cellos (2012) e Santos (2012), para que a partir deles, fosse elaborado um questionário próprio. Essa análise levou em conta às questões que havia em comum e que fosse relevante para essa pesquisa, tendo em vista a particularidade do local. Ainda, antes da aplicação do questionário, foi realizado um pré-teste.

Também foi necessário levar em conta que existe um método de análise de mobilidade urbana reconhecido mundialmente, o IMUS - Índice de Mobilidade Urbana Sustentável, desenvolvido por Costa (2008). Embora não seja o foco de tal trabalho, é necessário considerar a importância da tese no sentido de que essa criou parâmetros para analisar a mobilidade urbana, com variáveis que não podem ser desconsideradas quando se estuda tal tema.

O questionário foi aplicado em alguns pontos de ônibus da cidade, em dias alternados do mês, para uma amostra de 100 pessoas, todos usuários do transporte coletivo. Para análise dos dados, foi utilizado o programa SPSS.

\subsection{CONTEXTUALIZAÇÃO DA MOBILIDADE URBANA NA CIDADE DE SÃO MIGUEL DO OESTE - SC}

O número de veículos no Brasil é alarmante. De acordo com o Denatran, em abril de 2016, existiam 91.752 .330 de veículos em todo o país. Segundo o IBGE (2016), a estimativa de população para o país neste mesmo ano é de 205.988.722 habitantes, correspondendo a uma média simples de um veículo para cada 2,24 pessoas.

Se fosse possível imaginar todos esses veículos circulando ao mesmo tempo, certamente as cidades tornarse-iam um grande caos, haveria veículos disputando o espaço urbano com pedestres e ciclistas. Hoje, muitas cidades vêm procurando priorizar pessoas e reduzir espaços destinados a veículos (Gehl, 2013).

Pensar no transporte coletivo como solução para os problemas urbanos de tráfego ainda é um problema, pois o governo vê as grandes montadoras de veículos como símbolos de progresso e desenvolvimento (Scarlato, 1999).

O fato é que essas condições de priorização do veículo permanecerão por muito tempo, pelo fato de que as políticas de incentivo à produção, a venda e ao uso dos veículos privados prevalecerem sobre as medidas que possam vir a estimular o uso do transporte público e do transporte não motorizado (Carvalho, 2016).

Mascaró (2005) afirma que restringir ao máximo o deslocamento motorizado através da redução dos espaços destinados aos automóveis é a melhor maneira de construir espaços que promovam a convivência e que tenham como prioridade transportes não motorizados. 
A cidade de São Miguel do Oeste está situada no Extremo Oeste de Santa Catarina (Figura 1), região da Associação dos Municípios do Extremo Oeste Catarinense.

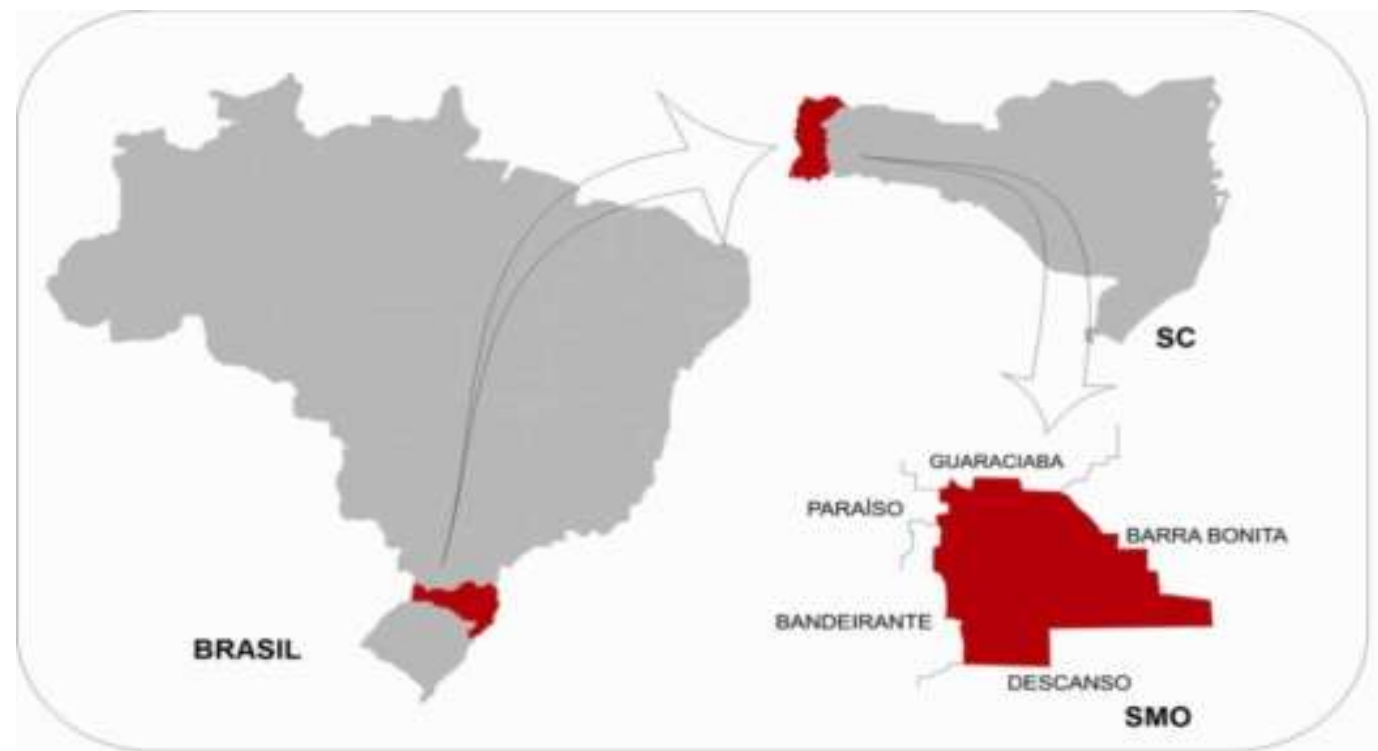

Figura 1. Localização do município de São Miguel do Oeste - SC.

Fonte: a autora.

Assim como a maior parte das cidades brasileiras, os números que o DENATRAN apresenta com relação ao número de frota de veículos é elevado para o município. Tendo uma população estimada em 39.390 pessoas, a frota de veículos corresponde a um total de 32.657 no ano de 2015 (DENATRAN, 2015), conforme pode ser verificado na ¡Error! No se encuentra el origen de la referencia..

\begin{tabular}{llll}
\hline Variável & São Miguel do Oeste & Santa Catarina & Brasil \\
\hline Automóveis & 17.707 & 2.655 .083 & 49.822 .708 \\
Caminhões & 1.118 & 146.819 & 2.645 .992 \\
Caminhões-trator & 437 & 48.607 & 593.892 \\
Caminhonetes & 3.049 & 336.393 & 6.588 .813 \\
Caminhonetas & 958 & 145.120 & 2.098 .233 \\
Micro-ônibus & 75 & 11.422 & 375.274 \\
Motocicletas & 5.177 & 815.722 & 20.216 .193 \\
Motonetas & 2.327 & 254.299 & 3.833 .159 \\
Ônibus & 113 & 18.702 & 590.657 \\
\hline Tratores & 10 & 2.996 & 30.371 \\
\hline Utilitários & 234 & 40.155 & 637.211 \\
\hline
\end{tabular}

Tabela 1: Número de veículos em São Miguel do Oeste, em Santa Catarina e no Brasil.

Fonte: Adaptado de IBGE, 2015. Elaborado pela autora.

Em abril de 2016, de acordo com dados do DENATRAN, o número de automóveis está em 17.841 veículos, o que representa um aumento pequeno, em números absolutos, mas expressivo levando em conta o porte do município. Caracteriza que em quatro meses, houve um aumento de 134 veículos circulando na malha urbana do município.

Com relação ao número de automóveis no ano de 2015, representado na Tabela 1, corresponde a um número de 17.707 , o que equivale a uma média de 0,45 automóveis por habitante no município de São Miguel do Oeste.

É preciso considerar que a maior parte dos meios de transporte utiliza queima de combustível ou gás (Figura 2;Error! No se encuentra el origen de la referencia.). Mais de $50 \%$ da frota de veículos que circulam no município, fazem uso do álcool ou gasolina para seu funcionamento, o que agrava problemas como efeito estufa, aquecimento global, crise ambiental, etc. Ainda, com relação aos principais poluidores no que tange aos combustíveis, o uso de álcool, gasolina e diesel correspondem juntos, a $96 \%$ do total. 


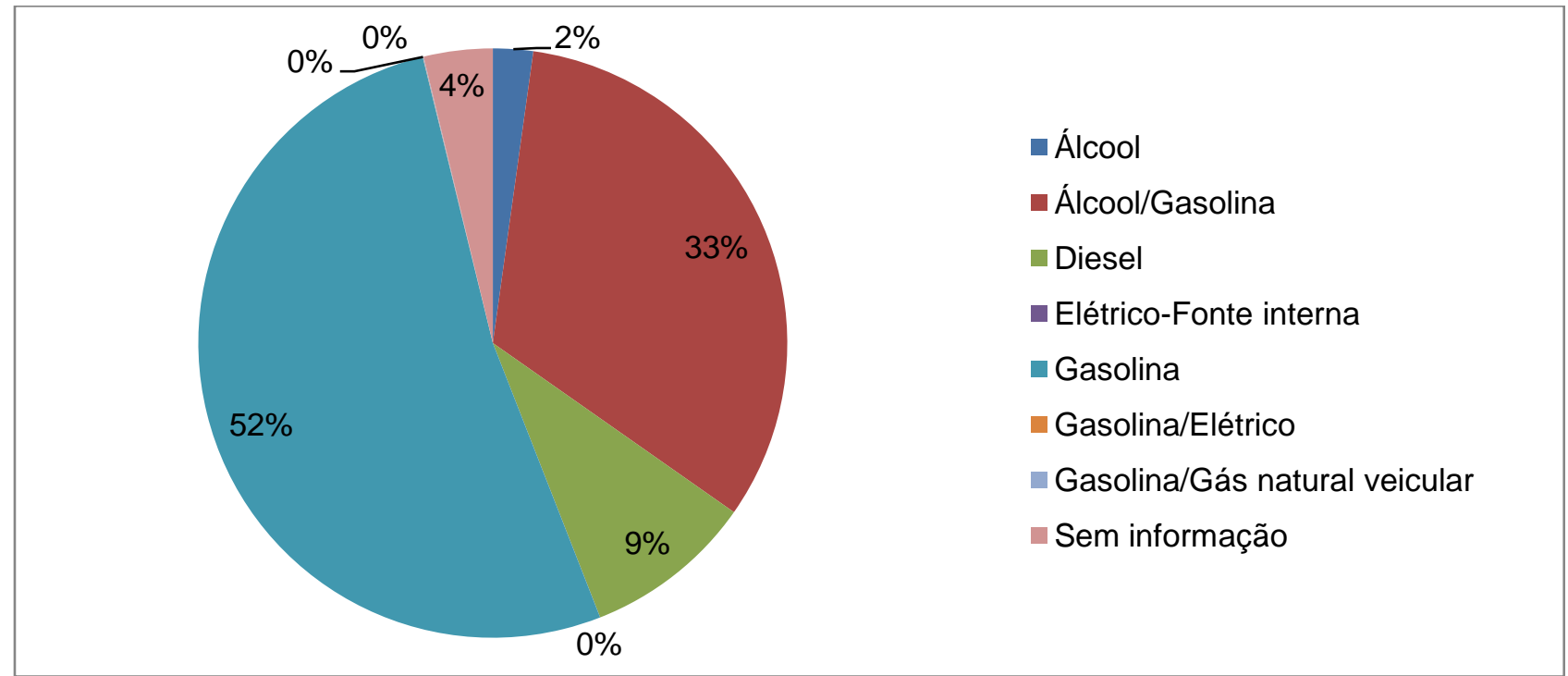

Figura 2. Tipo de combustível dos veículos no município

Fonte: DENATRAN (Abril de 2016), editado pela autora

Quanto à quantidade de veículos que o município de São Miguel do Oeste tem, é alarmante o crescimento com que esses números aparecem. Em 10 anos (Figura 3 ), esse número dobrou e teve, consequentemente, uma malha urbana com maior pavimentação asfáltica, maior número de vagas para estacionamento desses veículos e uma redução dos passeios públicos para que o sistema viário pudesse absorver esse crescente.

Aliando esse panorama a redução de IPI (Imposto sobre Produtos Industrializados) para compra de veículos novos, que acabou fazendo com que a população tivesse interesse e se sentisse convidada a adquirir um veículo próprio em condições e preços mais acessíveis, como uma alternativa para facilitar seus deslocamentos, seja para estudar, passear ou trabalhar.

Em contrapartida, não houve nenhum interesse ou incentivo para que a população se sentisse interessada ou motivada para utilizar de meios de transporte menos ou nada poluentes ou até mesmo, de um transporte coletivo urbano.

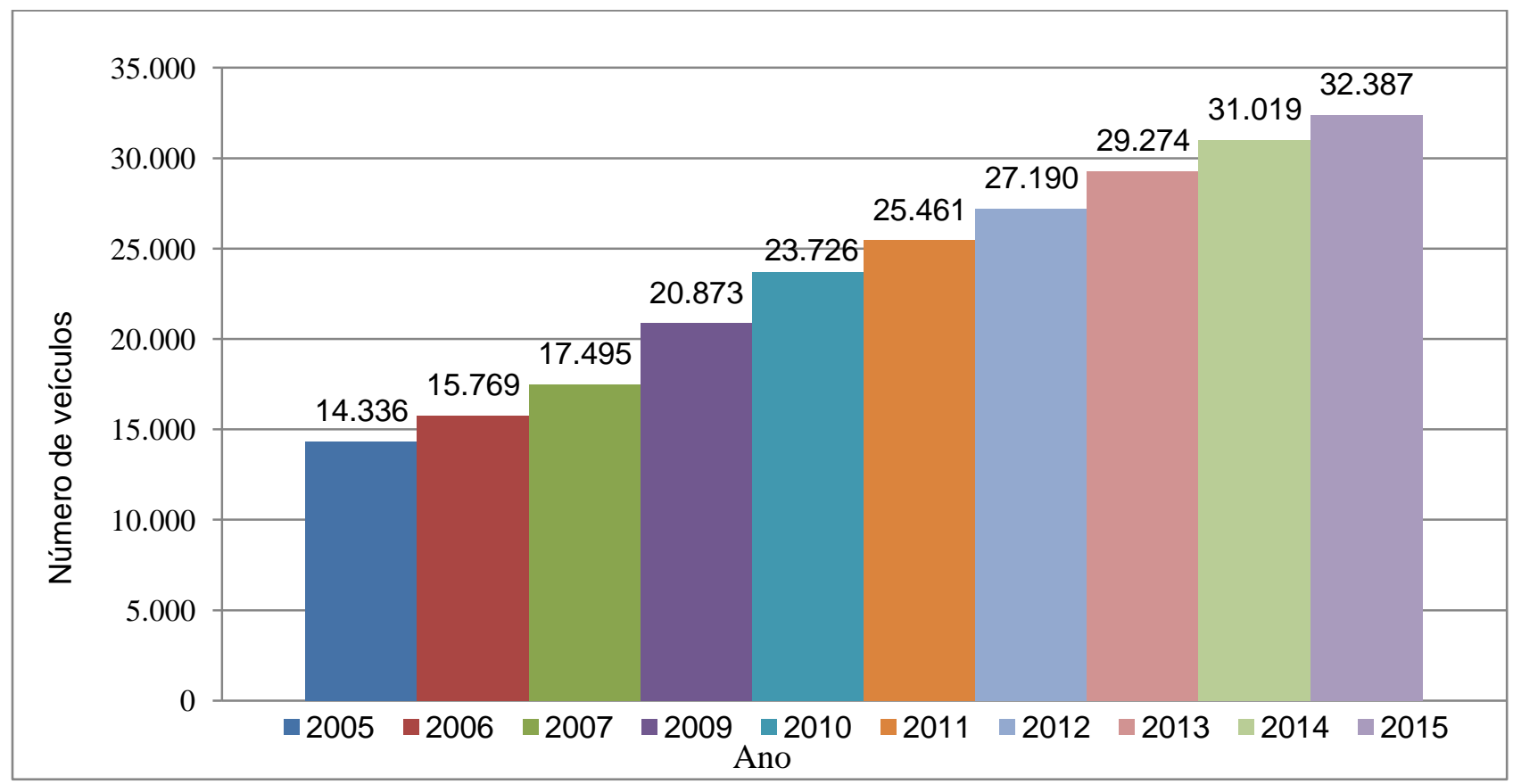

Figura 3. Número de veículos no município ao longo dos anos

Fonte: IBGE (2016), editado pela autora 
Ao que parece somente crianças e adolescentes não possuíam um tipo de veículo motorizado no município no ano de 2016. Questões voltadas ao tipo de uso de veículo ou ao tipo de combustível que o mesmo utiliza, referem-se também a questões sócio-histórico-culturais, já que muitos pensam apenas na facilidade momentânea ou imediata e também, no status que um veículo pode proporcionar. Para muitos, é vergonhoso utilizar de uma bicicleta, ir a pé ou utilizar de um transporte coletivo.

É necessária uma mudança também de pensamentos, uma quebra de paradigmas, aonde se consiga fazer com que as pessoas optem por soluções que também seriam ambientalmente sustentáveis.

Há uma necessidade também, de que sejam adotadas políticas públicas que possam vir a promover uma conscientização ou incentivo, para promover o uso de veículos que não dependam de combustíveis poluentes ou de recursos não renováveis.

De acordo com dados do IBGE (2010), o bairro que apresenta maior densidade demográfica é o bairro Sagrado Coração, seguido pelo Centro, São Luiz, Andreatta, São Jorge, Agostini, Jardim Peperi, Salete, Cohab, São Sebastião, São Gotardo, Progresso, Santa Rita e Estrela, respectivamente, conforme pode ser observado na Tabela 4.

\subsection{Sistema de Transporte Coletivo no município}

Com relação ao transporte coletivo, o município conta com um sistema que funciona de Segunda a Sextafeira durante todo o dia e aos Sábados, somente na parte da manhã. A concessão do serviço de transporte coletivo pertence a uma empresa que oferece serviços de meia passagem a alunos, gratuidade aos idosos e mantém parceria com algumas empresas, como forma de redução do valor.

Atualmente, conta com seis linhas, representadas por diferentes cores no mapa da Figura 4. Ainda, algumas vias recebem um fluxo maior de veículos deste tipo de transporte e tem uma característica de com melhor infraestrutura de tráfego e largura de via.

Entretanto, verifica-se que em boa parte dessas linhas não existe uma qualidade com relação ao passeio público, reflexo do fato do proprietário ser o responsável pela execução do passeio em frente ao seu lote, acarretando em não padronização ou falta de passeio que permitam acessibilidade.

Os mapas das Figura 4 e Figura mostram o raio de abrangência do transporte coletivo no município, a partir dos pontos ou paradas de ônibus, e corresponde a caminhabilidade dos usuários desse tipo de transporte. Considerou-se um raio de 300 metros, definido como uma boa caminhabilidade para Ferraz e Torres (2004) e está dentro dos 500 metros ideais definidos por Pitts (2004). O raio de caminhabilidade diz respeito a proximidade dos pontos de ônibus ao trabalho ou residência das pessoas que o utlizam.

Fica perceptível que alguns bairros, como os bairros Salete, São Luiz, Sagrado Coração de Jesus, São Gotardo e Progresso, possuem esse sistema apenas em suas bordas, mais próximas de ruas arteriais. Não obstante, a grande maioria dos bairros apresenta apenas paradas de ônibus, não um ponto, dotado de infraestrutura e conforto para que utilizem do transporte, como pode ser verificado na Figura. Ainda, pode ser observado que diversos locais estão abrangidos por mais de um ponto e parada, principalmente na área central.

Nota-se, em comparativo com o mapa da Figura 11, que os bairros Sagrado Coração de Jesus, Salete e São Jorge, uma parte do São Gotardo, Andreatta, Jardim Peperi e São Jorge, não são atendidos de forma total pelo transporte coletivo.

O sistema circula apenas em vias principais e está inserido de forma mais densa na área urbana central. Obviamente, pois nessa área localizam-se comércios e algumas empresas, sendo também, passagem para as instituições de ensino do município, no fluxo bairro x centro.

Outra característica do transporte coletivo é que existem poucas paradas de ônibus guarnecidas com característica física de abrigo (¡Error! No se encuentra el origen de la referencia., Figura, Figura ). A grande maioria se dá apenas pela locação de uma placa, sinalizando uma parada (Figura 9). Quanto à quantidade de cada uma, existem 25 pontos de ônibus com abrigos e 43 paradas. 


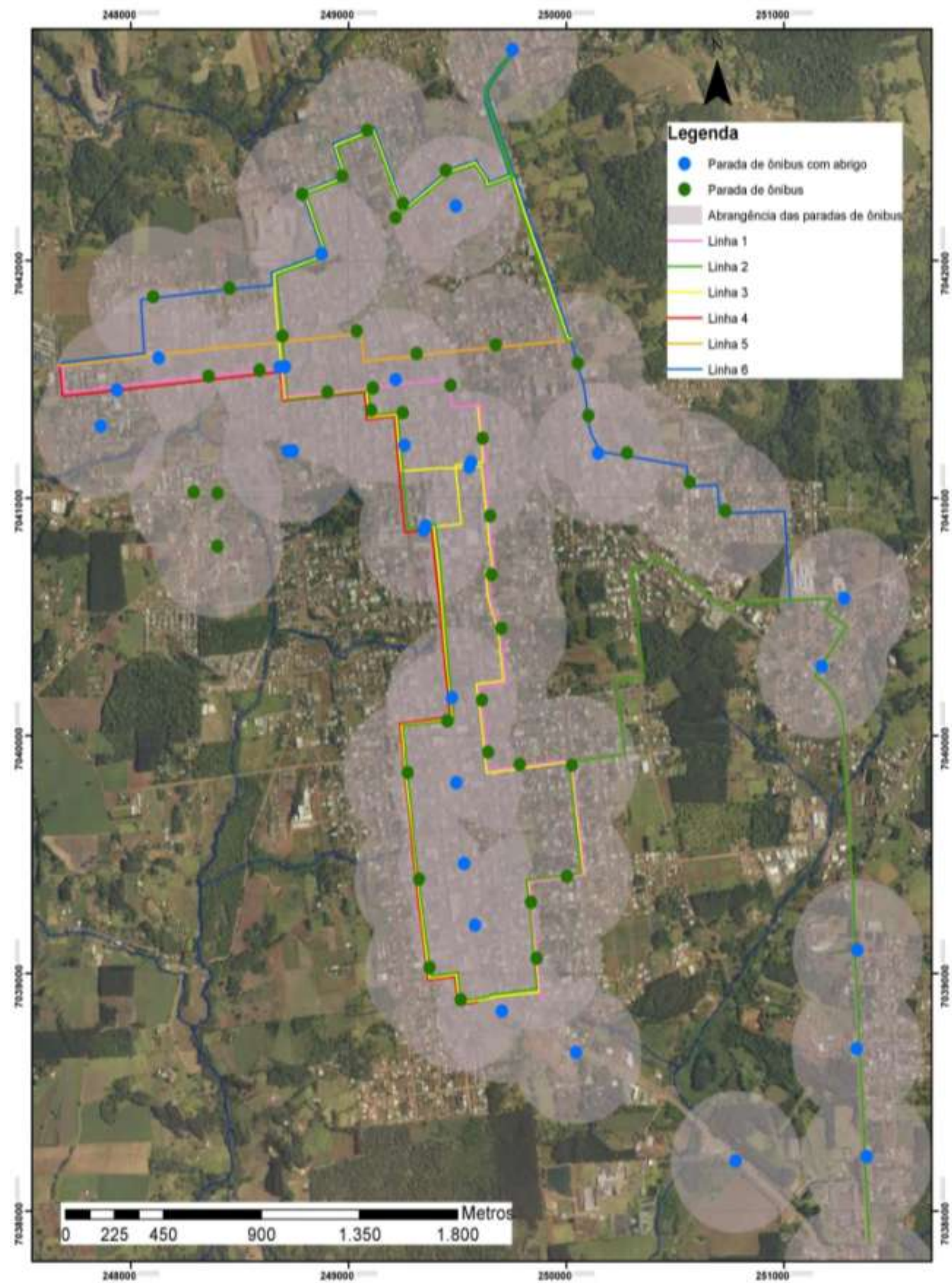

Figura 4: Mapa dos raios de abrangência dos pontos e das paradas de ônibus - imagem satélite

Fonte: Prefeitura Municipal de SMOeste, editado pela autora 


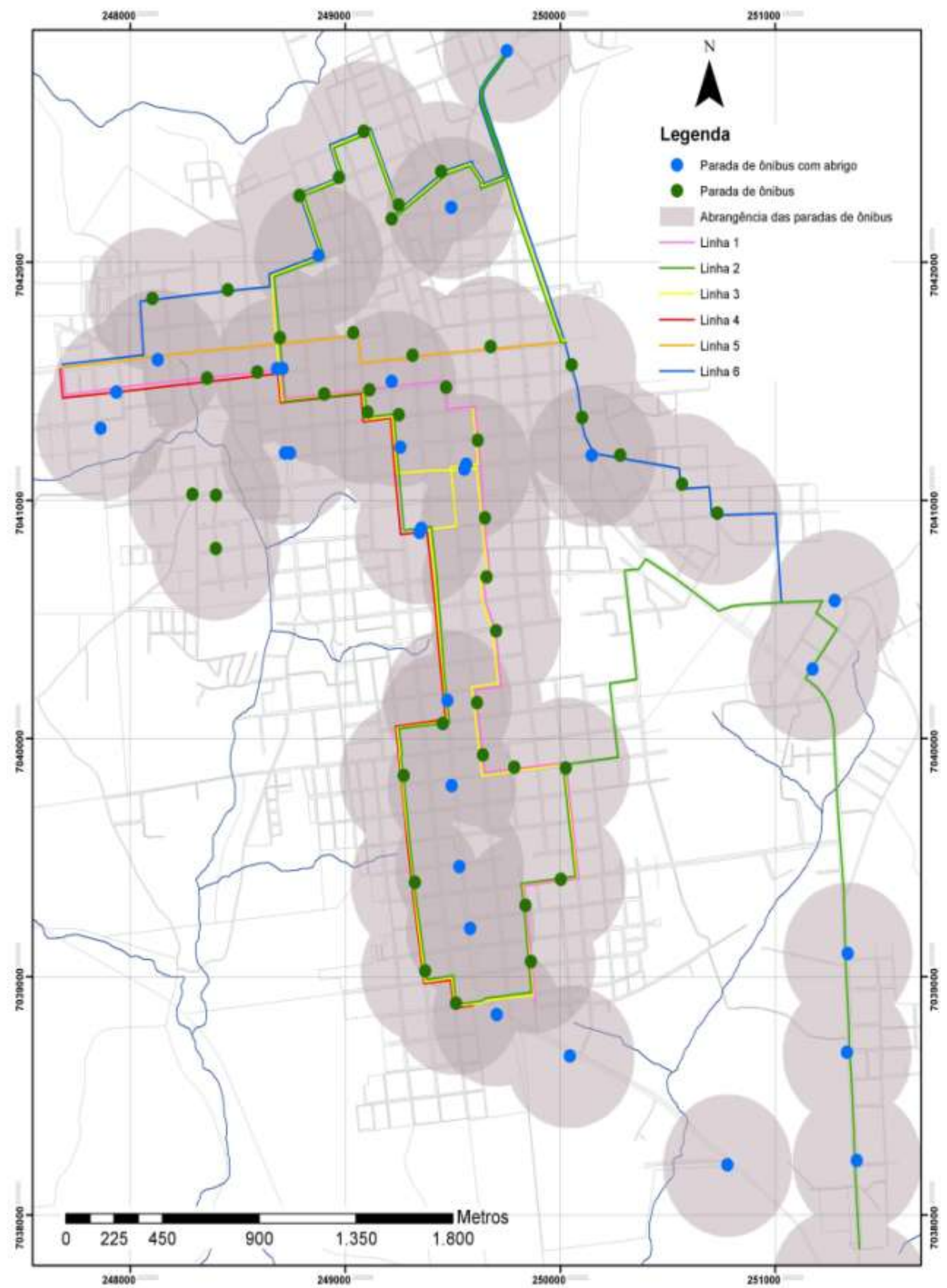

Figura 5: Mapa dos Raios de abrangência dos pontos e das paradas de ônibus Fonte: Prefeitura Municipal de SMOeste, editado pela autora 
O município não conta com um terminal urbano municipal que atenda somente o transporte coletivo, utilizando-se assim, do terminal urbano rodoviário, situado no centro da cidade.

Nota-se que nos pontos com abrigo (¡Error! No se encuentra el origen de la referencia., Figura, Figura), não há informação quanto aos horários das viagens. Em contato com a empresa, nem mesmo ela soube passar essa informação. Apenas os motoristas do transporte coletivo a detém e estes divulgam aos usuários através da distribuição de panfletos, o que dificulta ainda mais o uso desse tipo de veículo, já que apenas as pessoas que o utilizam com frequência sabem dos horários. A agência da empresa também disponibiliza essa informação, via contato telefônico.

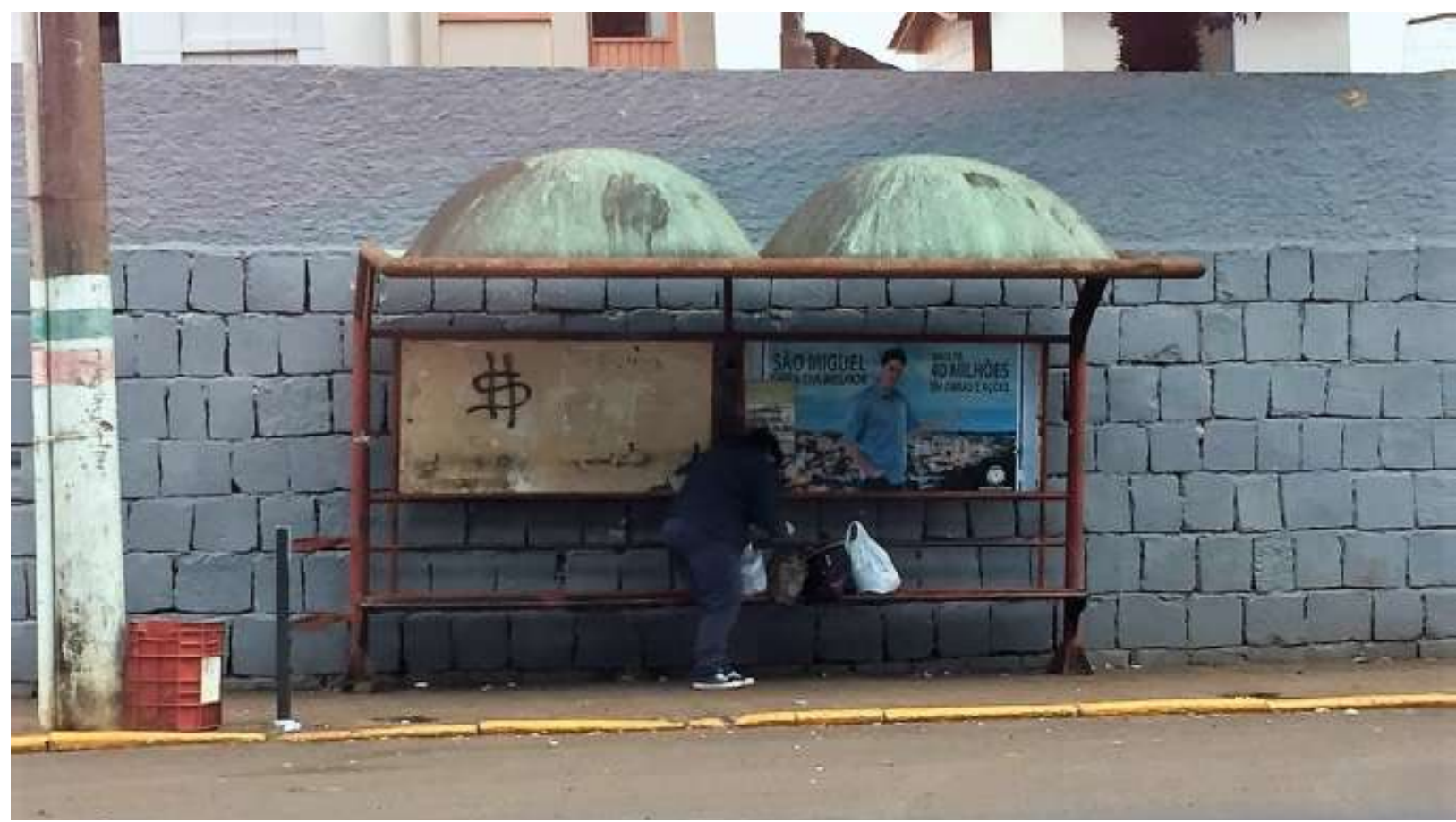

Figura 6: Ponto de ônibus com abrigo

Fonte: a autora (06/06/2016)

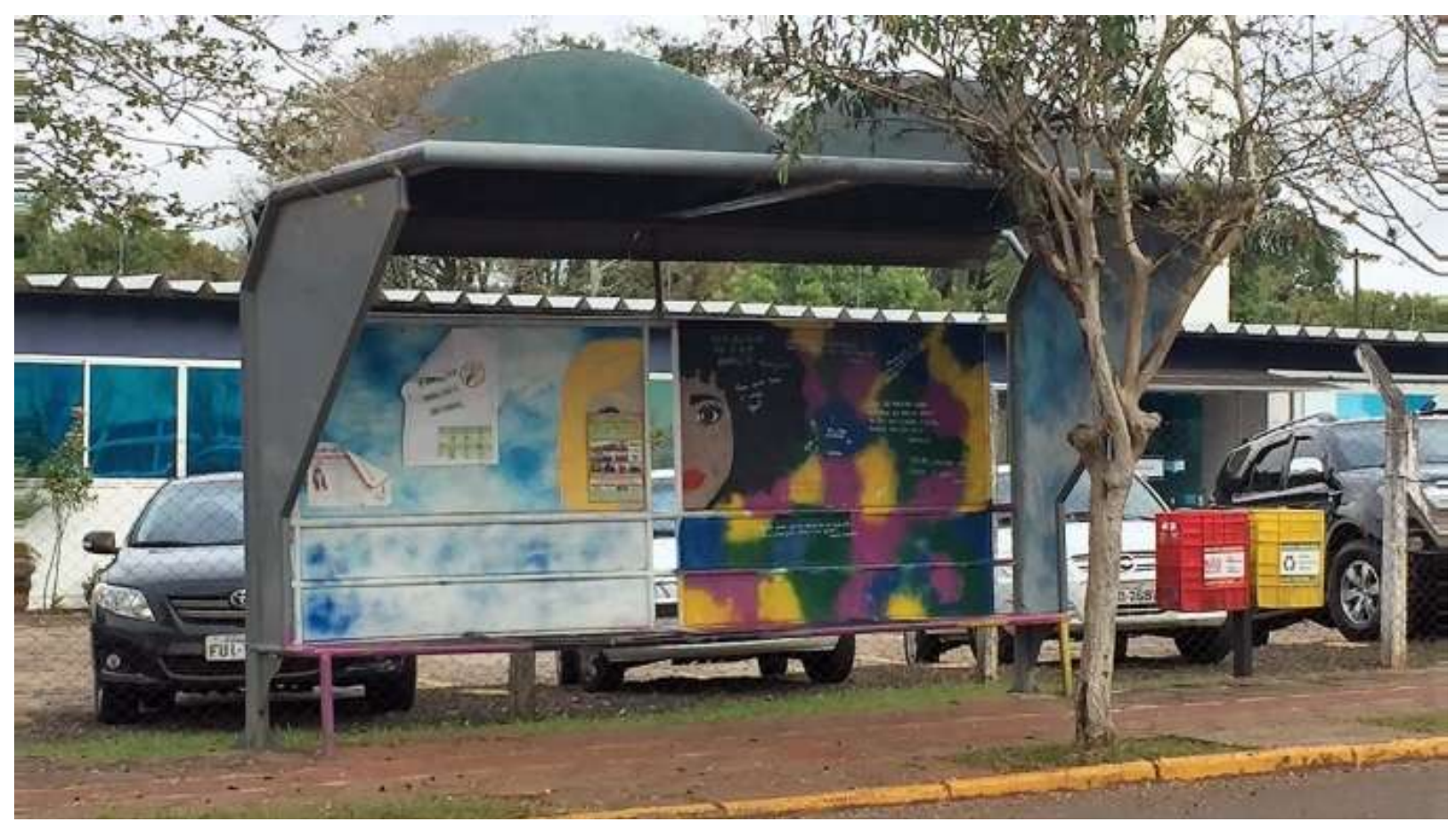

Figura 7: Ponto de ônibus com abrigo

Fonte: a autora (06/06/2016) 


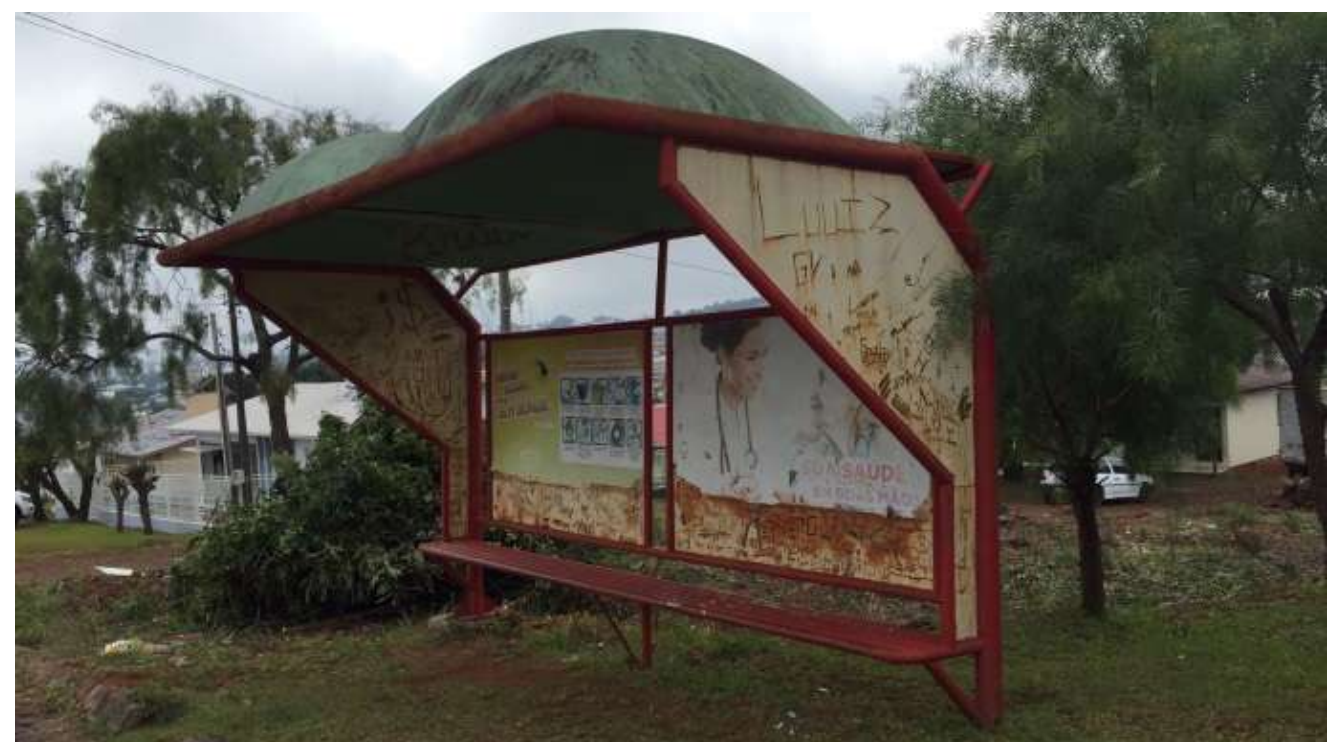

Figura 8: Ponto de ônibus com abrigo

Fonte: a autora (06/06/2016)

Pode ser verificado que alguns pontos dotados de abrigo sequer permitem acessibilidade ou oferecem boas condições de uso. A própria população acaba depredando os mesmos, pois mal consegue utilizá-lo (Figura 8). Ou também, estes acabam nem recebendo manutenção por parte do município, o que pode resultar nessa falta de cuidado.

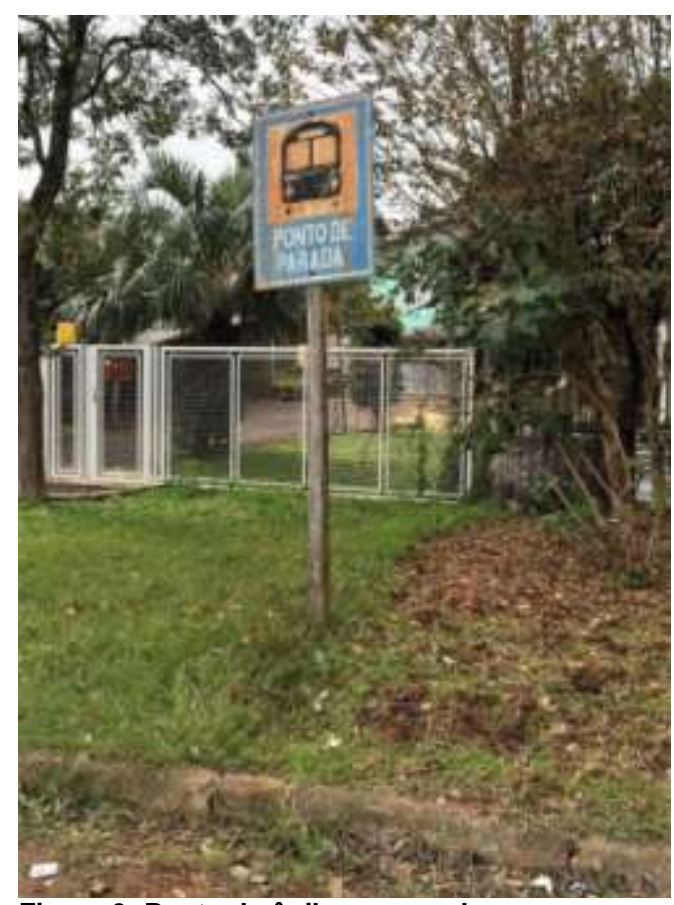

Figura 9: Ponto de ônibus - parada

Fonte: a autora (06/06/2016)

Quanto à acessibilidade e as calçadas, ao longo dessas vias, no ano de 2015, a Prefeitura Municipal, após ser notificada pelo Ministério Público Estadual, notificou toda a população devido à obrigatoriedade da pavimentação dos passeios públicos em frente ao seu lote. Embora o passeio caracterize-se como um espaço público, ele é de responsabilidade do proprietário.

Houve uma padronização de largura de passeio e de piso tátil e rebaixo de meio fio, mas não houve uma padronização quanto ao tipo de material utilizado, o que configura em uma falta de legibilidade e padronização. Isso não diz respeito necessariamente à beleza dos passeios, mas a usabilidade, haja vista que a diferença de materiais dificulta o trajeto de pessoas portadoras de deficiências, sejam elas físicas ou visuais. 
Quanto aos horários, cada linha circula entre seis a dez vezes por dia nesses trajetos, sendo que todos circulam pelo menos no início e fim da manhã, início e fim da tarde e início e fim da noite. Analisando a Figura 4, fica nítido que existem diversas manchas na malha urbana que não estão inseridas ou que são contempladas pelo sistema de transporte coletivo, se considerado um raio de abrangência de 300 metros, definido como uma boa caminhabilidade para os usuários do transporte coletivo (Ferraz e Torres, 2004; Pitts, 2004), a partir dos pontos e paradas de ônibus indicados no mapa cedido pela Prefeitura Municipal.

Fica perceptível que alguns bairros possuem esse sistema apenas em suas bordas, mais próximas de ruas arteriais. Não obstante, a grande maioria deles apresenta apenas paradas de ônibus, não um ponto, dotado de infraestrutura e conforto, como de um abrigo, para que utilizem o transporte. Ainda, pode ser observado que diversos locais estão abrangidos por mais de um ponto e paradas.

É preciso saber se o sistema vem sendo suficiente do ponto de vista do usuário para a demanda que se coloca, verificando o grau de satisfação com o serviço oferecido.

\subsection{Grau de satisfação do usuário}

Como forma de analisar o grau de satisfação do usuário do transporte coletivo no município, optou-se pela aplicação de um questionário do tipo survey aos usuários do mesmo. Este foi dividido em duas partes: a primeira, com questões de 1 a 12, compreendendo o perfil do usuário deste tipo de transporte. Esse perfil foi definido através das questões que podem ser verificadas na Tabela 2.

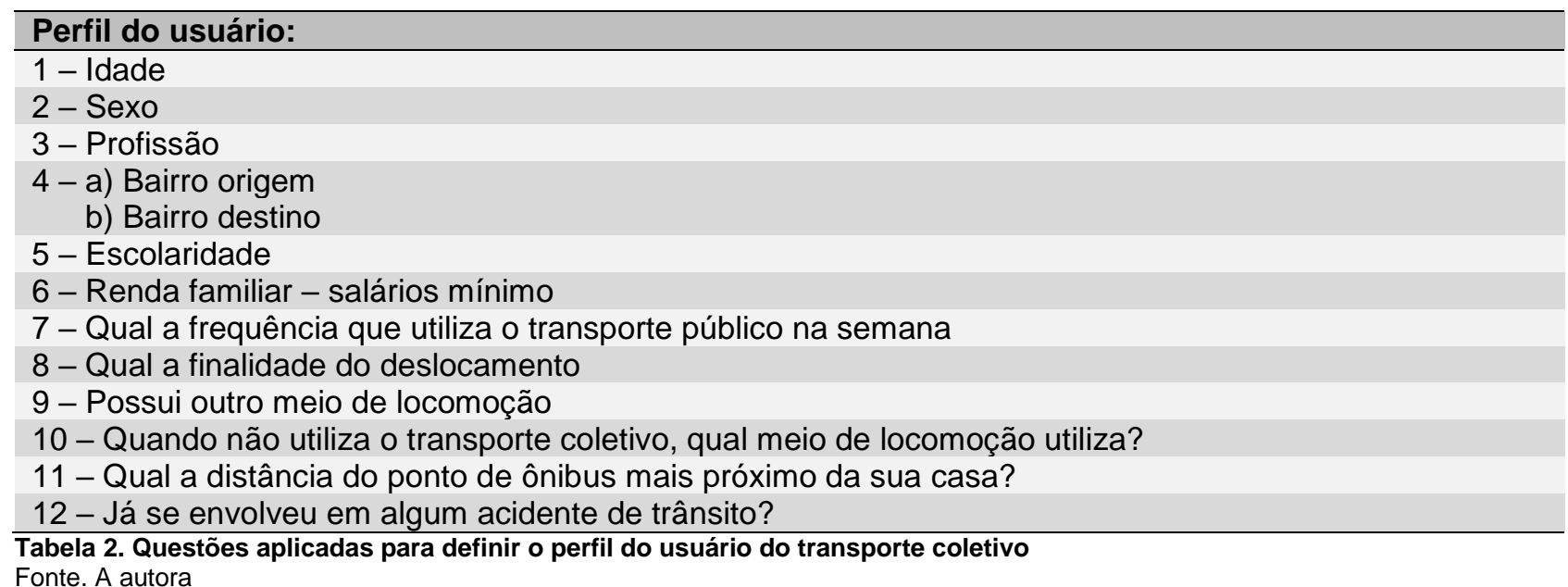

A segunda (Tabela 3) analisa o grau de satisfação do usuário do transporte coletivo com relação ao serviço prestado. As questões 13 a 34 e também foram analisadas através da frequência, trazendo a média e desvio padrão. As respostas se deram através da Escala de Likert, numa escala ordinal de 1 a 5 , sendo 1 classificado com péssimo, 2 como ruim, 3 como regular, 4 como bom e 5 como ótimo sendo.

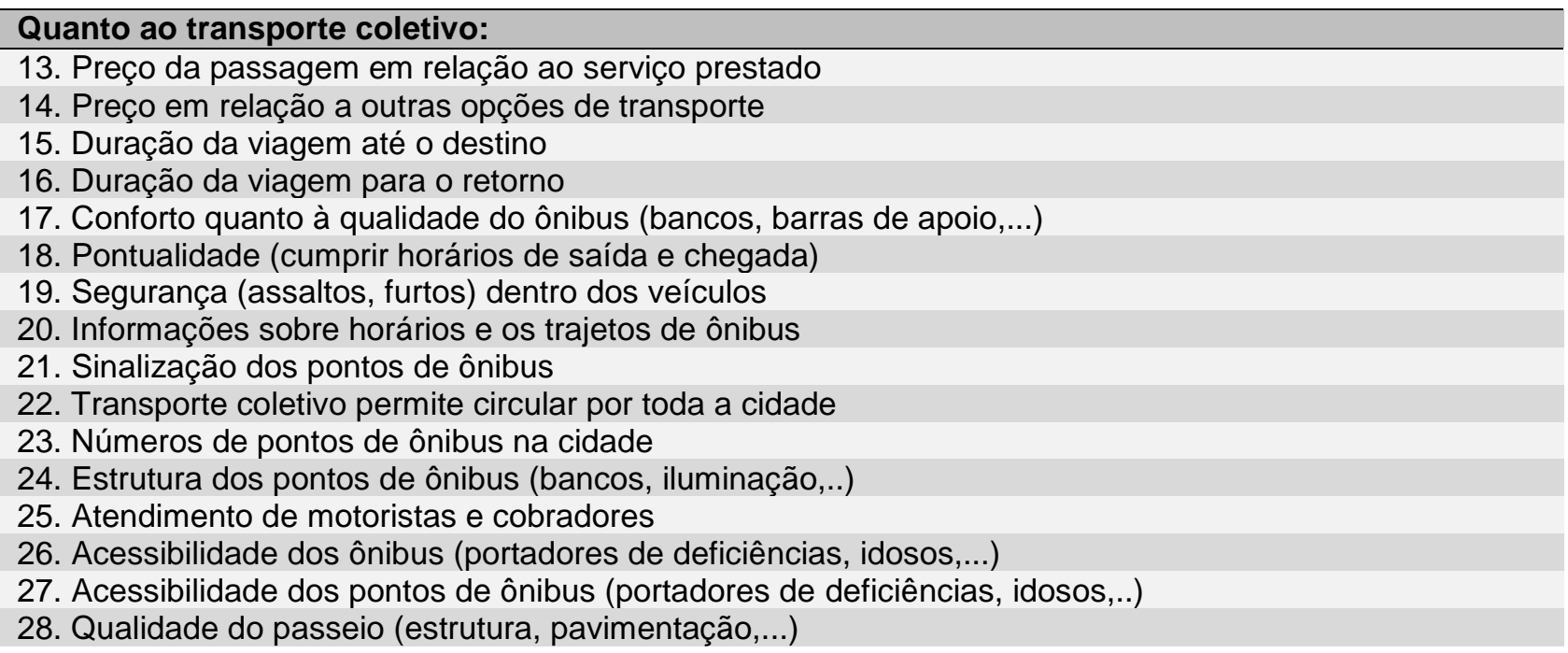


29. Horário dos ônibus nas linhas

30. Lotação - número de pessoas no ônibus

31. Estado de conservação do ônibus

32. Estado de conservação das vias em que o ônibus trafega

33. Distância entre os pontos

34. Acessibilidade do passeio até o ponto de ônibus (portadores de deficiências, idosos, ...)

Tabela 3. Questões aplicadas para verificar o grau de satisfação do usuário do transporte coletivo

Fonte: A autora

Essa segunda parte contempla ainda, as questões 35 e 36, respostas discursivas que tem como objetivo compreender se efetivamente os usuários tem conhecimento dos horários das linhas e sugestão para melhoria do transporte coletivo urbano no município.

Todas as questões foram analisadas a partir da análise de frequência, pela necessidade de compreender quais as variáveis que mais se repetiam, através de seus valores e terão resultados apresentados através de gráficos.

A partir do questionário aplicado para uma amostra de 100 respondentes, pode-se definir que o público usuário do transporte coletivo urbano no município é predominantemente de mulheres estudantes jovens, que utiliza o transporte para fins de trabalho e principalmente, estudo. Estes tem uma renda familiar média de dois a cinco salários mínimos e utilizam o transporte em torno de 4 a 5 vezes por semana.

Uma das questões que merece destaque, diz respeito à origem-destino da viagem, verificado na Figura .

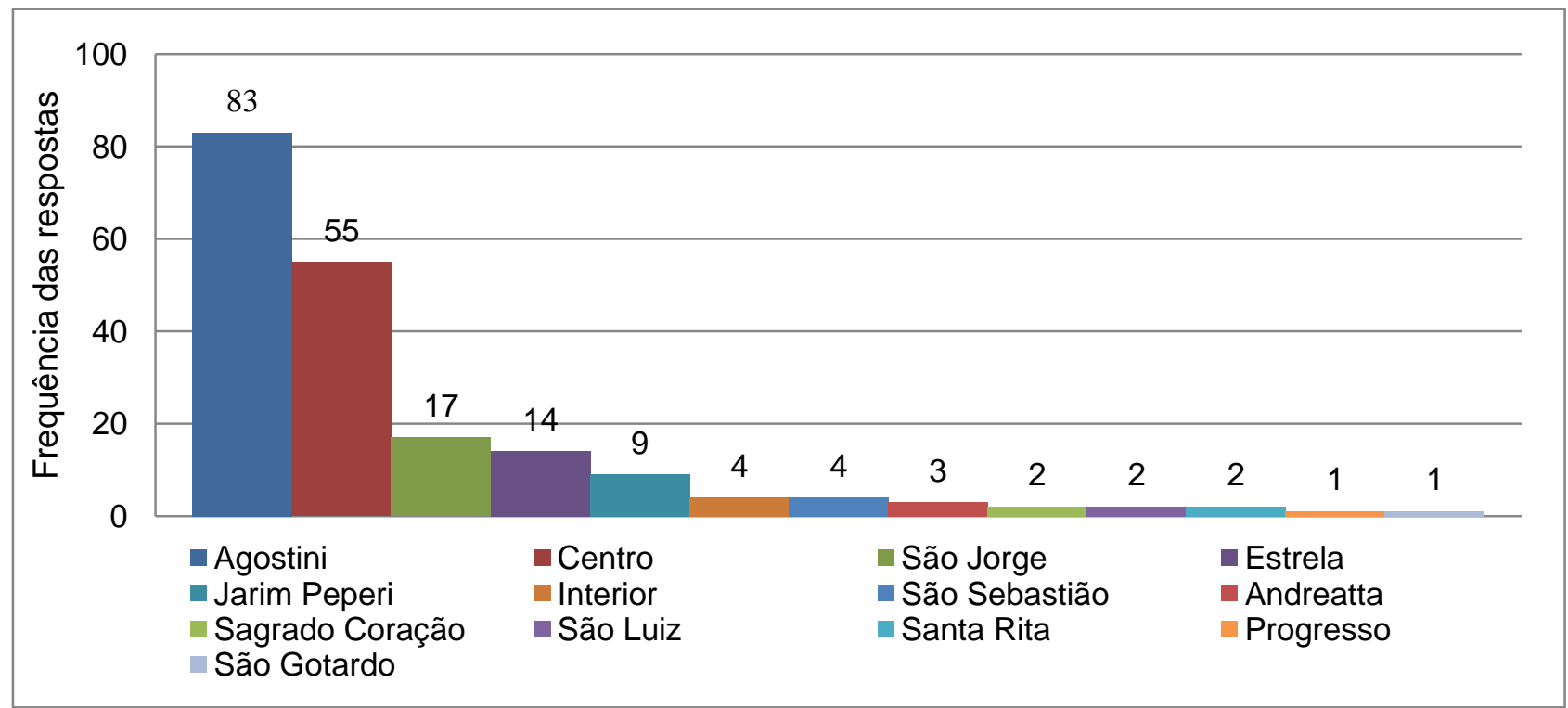

Figura 10: Bairros - geral

Fonte: A autora

O alto número tanto no destino de ida ou volta, para o bairro Agostini, fica claro pelo fato do mesmo ter inserido em seu interior duas instituições de ensino, a UNOESC - Universidade do Oeste de Santa Catarina e o SENAI - ServiçoNacional de Aprendizagem Industrial. O primeiro contempla ensino superior e poucos cursos técnicos enquanto o segundo oferece serviço de ensino médio e técnico.

O SENAC - Serviço Nacional de Aprendizagem Comercial também se encontra no início do bairro Agostini, o que também acarretam um grande fluxo de pessoas a esse destino. Ainda, existe próximo ao SENAC, uma escola de ensino técnico, o que também movimenta as linhas de transporte coletivo urbano.

De acordo com dados do IBGE (2010), o bairro que apresenta maior densidade demográfica é o bairro Sagrado Coração, seguido pelo Centro, São Luiz, Andreatta, São Jorge, Agostini, Jardim Peperi, Salete, Cohab, São Sebastião, São Gotardo, Progresso, Santa Rita e Estrela, respectivamente, conforme pode ser observado na Tabela 4. 


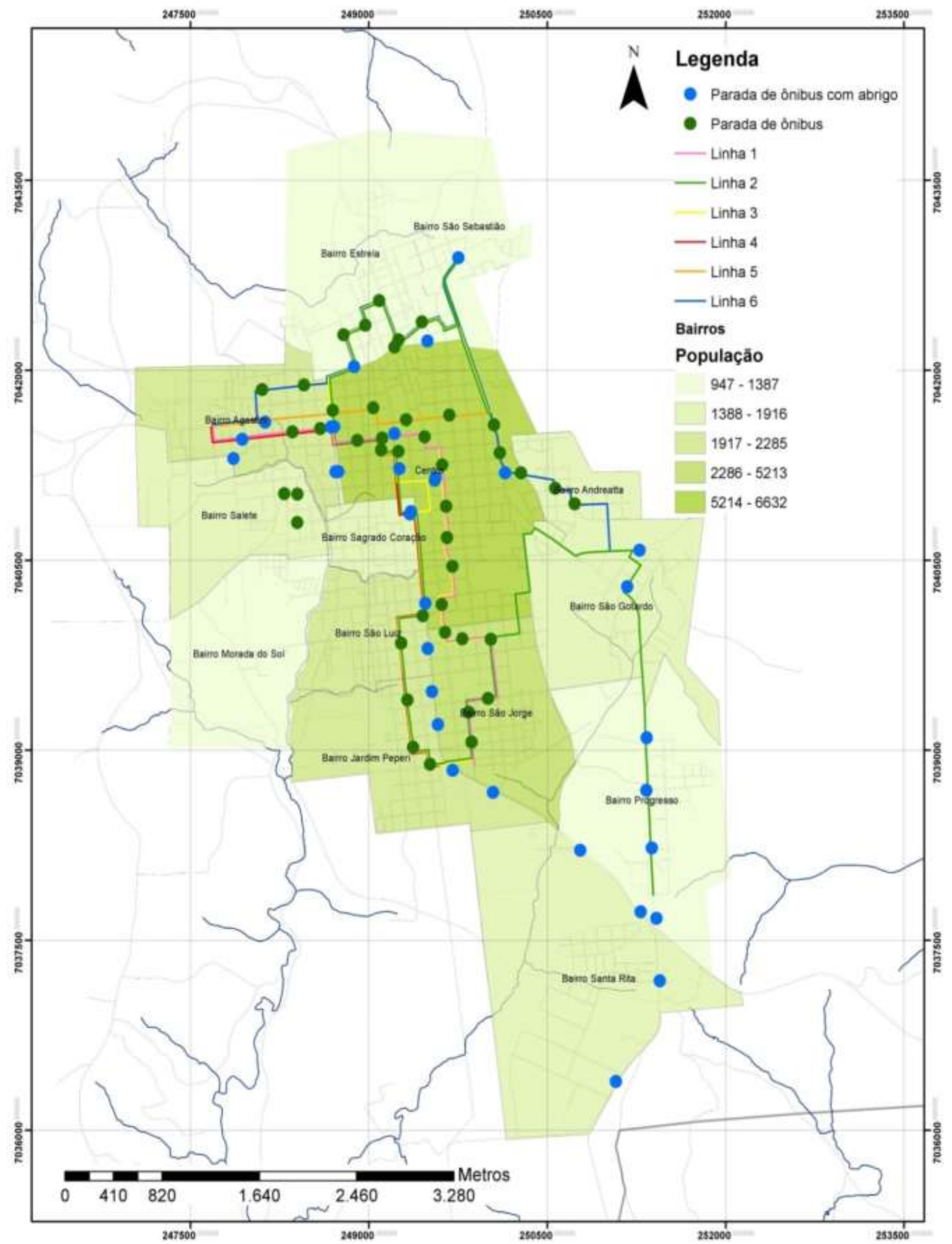

Figura 4. Mapa da população por bairro e dos pontos e paradas de ônibus

Fonte: Prefeitura Municipal de SMOeste. IBGE (2010) editado pela autora 
A média de densidade demográfica do município é de $155,012 \mathrm{hab} / \mathrm{km}^{2}$. Comparando a Tabela $4 \mathrm{com}$ os bairros que foram mais citados, não há a mesma lógica de uso do transporte coletivo com a densidade demográfica do mesmo. O mapa da Figura 4¡Error! No se encuentra el origen de la referencia., mostra a relação da população por bairro no município, de acordo com os dados do IBGE (2010).

Se compararmos o número de habitantes por bairro (Tabela 4), seria ideal que o sistema atingisse de forma mais regular os bairros que têm o maior número de habitantes. O centro consegue dar conta da demanda, pois conforme já analisado, o sistema todo acontece em torno da área central da cidade. O bairro Agostini também consegue ser atingido de forma ideal, pois precisa suprir a demanda das instituições de ensino.

\begin{tabular}{|c|c|c|c|}
\hline Bairro & $\begin{array}{l}\text { População } \\
\text { Residente }\end{array}$ & $\begin{array}{l}\text { Área do bairro } \\
\text { km² }^{2}\end{array}$ & $\begin{array}{l}\text { Densidade demográfica } \\
\text { hab/km² }\end{array}$ \\
\hline Centro & 6.632 & 27,089 & 244,82 \\
\hline Estrela & 947 & 20,755 & 45,62 \\
\hline São Sebastião & 1.116 & 8,964 & 124,49 \\
\hline Agostini & 2.072 & 12,885 & 160,80 \\
\hline Salete & 1.789 & 12,767 & 140,12 \\
\hline Andreatta & 1.643 & 6,825 & 240,73 \\
\hline Cohab & 1.022 & 15,162 & 67,40 \\
\hline São Luiz & 2.125 & 8,797 & 241,55 \\
\hline Sagrado Coração & 1.694 & 3,708 & 456,85 \\
\hline São Gotardo & 1.814 & 15,593 & 116,33 \\
\hline Jardim Peperi & 2.057 & 13,288 & 154,80 \\
\hline São Jorge & 2.604 & 13,617 & 191,23 \\
\hline Progresso & 1.221 & 20,821 & 58,64 \\
\hline Santa Rita & 1.586 & 32,643 & 48,58 \\
\hline
\end{tabular}

Tabela 4. Densidade demográfica por bairro no município

Fonte. IBGE, 2010. Elaborado pela autora

Entretanto, bairros como São Jorge, Jardim Peperi e São Luiz, embora sejam atendidos pelo transporte, possuem horários determinados de passagem, apenas em início de turno ou final. Não existem muitas alternativas de uso.

O sistema precisa não apenas levar em conta o trajeto, mas também, precisa permitir que a população possa ter possibilidades de uso, que não seja engessado em horários apenas destinados a estudo ou trabalho.

A maioria deles dispõe de outros meios de locomoção, principalmente carros, mais do que motos. Também, possuem pontos de ônibus próximo a sua residência, de até três quadras de distância e nunca se envolveu em nenhum tipo de acidente de trânsito. Pode-se assim, compreender como esse tipo de usuário, classifica o transporte que utiliza. Analisando de forma geral a Tabela 5, é possível perceber que a grande maioria das respostas se mantém entre regular, com pouca tendência para o bom. Isso indica que o transporte coletivo não está tão bom, e que muitas melhorias deveriam ou poderiam acontecer.

A média possibilita compreender a resposta do grupo como um todo, demonstrando que o grau de satisfação da grande maioria dos respondentes com relação a todas as variáveis, gira em torno de 3,0. Demonstra então, que o transporte coletivo urbano no município não está tão ruim, mas está longe de um ideal.

A questão 24 elucida a pior variável analisada, classificada como ruim. Ela diz respeito a estrutura dos pontos de ônibus (bancos, iluminação..). Essa situação fica clara quando da análise da qualidade dos pontos e paradas, já mostrados nesta discussão quando existem diversas paradas de ônibus sem estrutura física de abrigo ou sequer placa de informação. Essa situação é reforçada, quando da análise das respostas discursivas trazidas para o questionário. Dos 100 respondentes, 17 trazem como sugestão para a melhoria do transporte urbano coletivo, alguma relação com a qualidade dos pontos de ônibus. Essa deveria ser uma questão prioritária para fomentar o uso do transporte coletivo no município. 


\begin{tabular}{|c|c|c|c|c|c|c|c|}
\hline & \multicolumn{5}{|c|}{ Classes - Frequência (\%) } & \multirow{2}{*}{ Média } & \multirow{2}{*}{ Desvio Padrão } \\
\hline & Péssimo & Ruim & Regular & Bom & Ótimo & & \\
\hline P.13 & 1,0 & 15,0 & 48,0 & 19,0 & 7,0 & 3,26 & 0,83630 \\
\hline P.14 & 1,0 & 10,0 & 46,0 & 39,0 & 4,0 & 3,35 & 0,75712 \\
\hline P.15 & 1,0 & 11,0 & 33,0 & 48,0 & 8,0 & 3,50 & 0,83485 \\
\hline P.16 & 1,0 & 10,0 & 31,0 & 50,0 & 8,0 & 3,54 & 0,82168 \\
\hline P.17 & 1,0 & 15,0 & 41,0 & 31,0 & 12,0 & 3,38 & 0,91872 \\
\hline P.18 & - & 12,0 & 27,0 & 48,0 & 13,0 & 3,62 & 0,86199 \\
\hline P.19 & - & 3,0 & 14,0 & 53,0 & 30,0 & 4,10 & 0,74536 \\
\hline P.20 & 4,0 & 18,0 & 38,0 & 34,0 & 6,0 & 3,20 & 0,94281 \\
\hline P.21 & 4,0 & 17,0 & 48,0 & 28,0 & 3,0 & 3,09 & 0,85393 \\
\hline P.22 & 4,0 & 22,0 & 33,0 & 31,0 & 10,0 & 3,21 & 1,02784 \\
\hline P.23 & 3,0 & 20,0 & 47,0 & 29,0 & 1,0 & 3,05 & 0,80873 \\
\hline P.24 & 7,0 & 42,0 & 31,0 & 17,0 & 3,0 & 2,67 & 0,94340 \\
\hline P.25 & 1,0 & 6,0 & 25,0 & 51,0 & 17,0 & 3,77 & 0,83913 \\
\hline P.26 & 9,0 & 24,0 & 32,0 & 30,0 & 5,0 & 2,98 & 1,05390 \\
\hline P.27 & 8,0 & 34,0 & 35,0 & 22,0 & 1,0 & 2,74 & 0,92791 \\
\hline P.28 & 7,0 & 21,0 & 48,0 & 22,0 & 2,0 & 2,91 & 0,88877 \\
\hline P.29 & 3,0 & 19,0 & 47,0 & 28,0 & 3,0 & 3,09 & 0,84202 \\
\hline P.30 & 5,0 & 8,0 & 46,0 & 37,0 & 4,0 & 3,27 & 0,86287 \\
\hline P.31 & 5,0 & 10,0 & 32,0 & 44,0 & 9,0 & 3,42 & 0,96588 \\
\hline P.32 & 10,0 & 32,0 & 35,0 & 22,0 & 1,0 & 2,72 & 0,95431 \\
\hline P.33 & 2,0 & 21,0 & 46,0 & 27,0 & 4,0 & 3,10 & 0,84686 \\
\hline P.34 & 13,0 & 30,0 & 43,0 & 13,0 & 1,0 & 2,59 & 0,91115 \\
\hline
\end{tabular}

Tabela 5. Grau de satisfação do usuário

Fonte: A autora

Outro fator marcante é o desconhecimento dos usuários, dos horários do transporte coletivo urbano. A grande maioria das pessoas não sabe de quanto em quanto tempo o transporte coletivo passa na linha que costuma utilizar, o que fica reforçado pela diversidade de respostas na questão 35 , o que poderia ficar esclarecido caso houvesse uma estrutura melhor dos pontos de ônibus.

As questões 15, 16, 18, 19, 25 e 31 foram variáveis classificadas como bom pelos usuários. As questões 15 e 16 dizem respeito a duração da viagem de destino e retorno, o que caracteriza a duração da viagem como algo que não cause transtorno aos usuários. Com relação a essa situação, houve reclamações na resposta discursiva, com relação à impontualidade e atraso da chegada do ônibus nos pontos e parada, o que diferente da maioria dos respondentes, que classificaram como boa a pontualidade, de acordo com a questão 18.

A questão 19 diz respeito a segurança dentro dos veículos, o que demonstra que não devem acontecer assaltos ou furtos dentro dos mesmos. O atendimento dos motoristas e cobradores também é algo considerado bom para os usuários. Outro fator positivo é o estado de conservação dos ônibus. Essas são questões que não causam tanta preocupação com relação a esse tipo de transporte, mas que poderiam ser potencializadas.

Os respondentes consideraram como regular as variáveis $13,14,17,20,21,22,23,26,27,28,29,30,32$, 33 e 34. Essas são questões que requerem uma atenção especial, pois representam o maior grupo de variáveis. As questões 13 e 14 dizem respeito ao preço da passagem com relação ao serviço prestado e com relação a outras opções de transporte, o que indica que o custo é considerado alto pelo serviço que é oferecido e que outras opções de transporte ficam com um valor aproximado a essa opção. Atualmente, o valor da passagem corresponde a um valor de $\mathrm{R} \$ 3,00$. Esse valor se reduz a meia passagem para estudantes.

A questão 17 traz sobre o conforto quando à qualidade do ônibus (bancos, barra de apoio lateral, barras de apoio superior,...). É necessário que se tenha mais atenção ao conforto do usuário. As questões 20,21 e 23, dizem respeito a informações sobre horários e os trajetos de ônibus, a sinalização dos pontos de ônibus e o número de pontos de ônibus na cidade, obstáculos para o uso desse transporte.

Pode ser verificado no mapa 03, que existe um grande número de paradas e pontos de ônibus na cidade, porém, como as paradas só tem uma placa de indicação, sem pontos físicos, as pessoas não os reconhecem como parte desse sistema. 
A questão 22 trata sobre o transporte coletivo circular por toda a cidade. Nota-se que, assim como observado nos mapas da ¡Error! No se encuentra el origen de la referencia. 4 e da Figura 5, o transporte coletivo apresenta manchas não contempladas por esse sistema e que reflete na pergunta dos respondentes. Uma moradora informou ainda, na questão discursiva, que o transporte não circula no bairro que mora.

A acessibilidade dos ônibus, acessibilidade dos pontos de ônibus para portadores de deficiências, idosos, etc.. e acessibilidade do passeio até o ponto de ônibus foram tratadas nas questões 26,27 e 34 , e mostram uma preocupação com os usuários, pela limitação que esse não cumprimento acarreta. É preciso que o transporte permita a todas as pessoas circularem e se deslocarem pela cidade.

A qualidade do passeio, em termos de estrutura e pavimentação ter sido considerada regular na questão 28, pode estar incluída na acessibilidade e demonstra que existe a necessidade de melhorar a qualidade desse atributo.

Voltando ao horário dos ônibus nas linhas, a questão 29 foi classificada como regular para os usuários. Existe então, uma necessidade de que o ônibus circule com maior frequência nas linhas e que também, a distância entre os pontos seja menor, como demonstrou a questão 33.

A lotação diz respeito ao número de pessoas, trazida na questão 30 . Esse fato deve ocorrer em horários de pico, principalmente na linha que leva até o bairro Agostini, em função das aulas. A questão 32 diz respeito ao estado de conservação das vias em que o ônibus trafega e mostra a necessidade de manutenção nas vias do município.

Analisando as questões $24,26,27,28,33$ e 34 , que tratam das estruturas dos pontos de ônibus, acessibilidade dos pontos e dos ônibus, qualidade do passeio, distância entre os pontos e acessibilidade do passeio até o ponto de ônibus. É possível perceber que, em todas as variáveis há uma tendência de predomínio de respostas ruins e regulares, o que demonstra uma insatisfação com relação a estrutura das paradas ou pontos de ônibus, bem como da acessibilidade dos mesmos.

A questão 35 procura compreender qual o conhecimento do usuário quanto ao horário dos ônibus na linha, pedindo a cada quanto tempo passa um ônibus. Nota-se claramente que não há um conhecimento quanto ao horário desse transporte, gerando respostas diversas com horários bastante diferenciados entre elas. Isso também se deve ao fato de que em alguns bairros, o transporte coletivo circula menos vezes do que em outros, ou também, pelo fato do centro receber mais linhas que passam por ele.

Já a questão 36, pede alguma sugestão para melhoria do transporte urbano coletivo. Nota-se como predominância a sugestão para as melhoras dos abrigos, paradas e informações quanto aos horários.

Assim, o transporte coletivo abrange o município como um todo, entretanto, no que tange a qualidade do mesmo e a infraestrutura que oferece para o usuário, é preciso que sejam adequadas ou melhoradas para o uso. Essa melhoria poderia inclusive, contribuir para o aumento de usuários desse tipo de transporte.

\section{CONCLUSÃO}

Estudar mobilidade urbana em uma cidade de menor porte é um desafio, pois muito se questiona o fato de cidades com esse porte não apresentarem problemas, haja vista a dimensão física do seu território ou o número de habitantes. Entretanto, a história nos mostra que todas as cidades sofrem com problemas voltados a esse atributo e que, não é necessário que este se torne insustentável para propor soluções ou começar a pensar em alternativas para impedir que o problema aconteça. Há um longo caminho a ser percorrido para a conscientização da população e dos gestores quanto a essa situação.

São Miguel do Oeste é conhecida como cidade polo do extremo oeste catarinense e no que tange a mobilidade urbana, acaba recebendo um grande número de veículos diariamente em seu sistema viário, seja por comércio, saúde ou lazer. Pensar em mobilidade urbana voltada à escala do pedestre permitiria que não apenas a população se sentisse convidada a circular mais pela cidade, mas também, as pessoas que se deslocam à cidade apenas com uma finalidade e já retornam as suas cidades de origem.

O Plano Diretor do município de São Miguel do Oeste, embora traga a obrigatoriedade do Programa de Mobilidade Urbana até um determinado prazo, e este não tenha sido implantado até então, bem como, pelo 
não cumprimento do que trazia a Política Nacional de Mobilidade Urbana, não implica necessariamente em um prejuízo para o município.

O Plano Diretor prevê algumas diretrizes para a valorização de meios de transporte ambientalmente sustentáveis, pela criação da ciclovia, a qual também não foi implantada no município. O Programa de Mobilidade viria como um grande incentivador para que a mobilidade urbana não fosse mais definida ao acaso, ou com soluções apenas imediatistas, mas em longo prazo.

O município dispõe ainda de transporte coletivo, que atinge quase que a malha urbana como um todo. Alguns bairros não são contemplados de forma total pelo transporte, o que pode impossibilitar ou ser um empecilho para o uso. O público usuário desse tipo de transporte é formado essencialmente por mulheres, que o utilizam para fins de estudo, o que acarreta ainda, no fato Bairro Agostini ser um dos destinos principais dos usuários, por nele estar localizada boa parte das instituições do ensino do município.

Há um descontentamento do usuário com relação à falta de infraestrutura dos pontos e paradas de ônibus, o que também pode promover o não uso do transporte coletivo por muitas pessoas.

É necessário compreender a mobilidade urbana também, através a qualidade dos passeios disponíveis para circulação de pedestres e ciclistas ou a acessibilidade que permite etc. Também, pensar nas possibilidades de tipos de transporte, tão egoístas atualmente, reflexo de um urbanismo modernista que esqueceu a importância das pessoas e priorizou o automóvel, muito influenciado pela revolução industrial.

É importante que se pense no sistema de transporte coletivo urbano, atrelado às áreas de expansão imediata, determinadas pelo Plano Diretor, permitindo e possibilitando que os novos loteamentos também possam usufruir desse serviço. Há uma tendência de crescimento para bairros em específico, como Agostini e Estrela. Assim, seria importante que esses bairros tivessem em seu planejamento, algo relacionado não apenas a expansão física ou territorial, mas também, a expansão do sistema.

Obviamente que pensar no sistema levando em conta a expansão não é algo fácil, mas poderiam ser criadas linhas que pudessem ter continuidade, levando em conta algumas vias estruturais ou arteriais.

O Bairro Agostini merece uma atenção diferenciada no que tange a esse sistema. Aliando o crescimento de novos loteamentos ao elevado número de usuários do transporte coletivo, a criação de linhas com maior regularidade de horários permitiria um melhoria na qualidade do fluxo de deslocamento desse bairro.

A mobilidade urbana vem sendo um dos maiores problemas que as cidades têm enfrentado e certamente, significam um problema para os gestores, pois soluções para essa situação não se dão de forma rápida e com baixo custo. Implica também no rompimento de valores instituídos na sociedade, que valoriza tanto meios de deslocamentos egoístas, como carros, por exemplo, e não de meios de locomoção coletivos ou que minimizem impactos ao meio urbano.

\section{BIBLIOGRAFIA}

BRASIL, 2001. Lei ํo10.257 de 10 de Julho.

—, 2012. Lei ํำ12.587 de 03 de Janeiro.

—, 2007. Caderno de Referências para Elaboração de Plano de Mobilidade Urbana.

CARVALHO, C. H. R., 2016. Desafios da mobilidade urbana no Brasil. Instituto de Pesquisa Econômica Aplicada (Ipea), Brasília. Disponível: http://repositorio.ipea.gov.br/bitstream/11058/6664/1/td_2198.pdf. Consulta: 08 jul. 2016.

CELLOS, Riani M. C.; SILVA JUNIOR, Carlos A. da; FONTENELE, Heliana B. Análise da qualidade do transporte público urbano por ônibus sob a ótica do usuário idoso. Revista de Engenharia $e$ Tecnologia, Vol. 4, no 3, p. 71, 2012.

COSTA, M. S., 2008. Um índice de mobilidade urbana sustentável. Tese (Doutorado). São Carlos, USP. 
DENATRAN. Departamento Nacional de Trânsito. 2016. Disponível: http://www.denatran.gov.br/frota2016.htm. Consulta: 26 mai. 2016.

GEHL, J., 2013. Cidades para Pessoas. $2^{\underline{a}}$ edição. São Paulo, Perspectiva.

FERRAZ, A. C. P., TORRES, I. G. E., 2004. Transporte público urbano. São Carlos. Rima.

IBGE (2010). Dados do Município de São Miguel do Oeste. Disponível: http://www.cidades.ibge.gov.br/xtras/perfil.php?lang=\&codmun=421720\&search=||infogr\%E1ficos:-

informa\%E7\%F5es-completas. Consulta: 12 Jul. 2015.

IBGE, 2016. Dados da população brasileira e veículos. Disponível: http://www.ibge.gov.br/home/. Consulta: 08 mar. 2016.

MASCARÓ, J. L., 2005. Loteamentos Urbanos. Porto Alegre, Edição do autor.

PITTS, A., 2004. Planning and Design Strategies for Sustainbility and profit: Pragmatic sustainable design on building and urban scales. Elsevier, Architectural Press.

SANTOS, Jorge Padilha dos. Transporte Coletivo Público Urbano na cidade de Santiago - RS. Estudo da percepção dos usuários quanto à acessibilidade e nível do serviço prestado. $141 \mathrm{f}$. Programa de PósGraduação em Planejamento Urbano e Regional (PROPUR). Universidade Federal do Rio Grande do Sul UFGRS. Santiago, 2012.

SCARLATO, F. C., PONTIN, J. A.; coordenação FURLAN, S. A., 1999. O ambiente urbano. São Paulo, Atual.

SILVA, E. F., 2014. Meio ambiente \& mobilidade urbana. São Paulo, Editora Senac São Paulo. 